\title{
Compositional and sensory differences of products of sweet-cream and whey buttermilk produced by microfiltration, diafiltration, and supercritical $\mathrm{CO}_{2}{ }^{1}$
}

\author{
A. Olabi, ${ }^{2}$ S. Jinjarak, † R. Jiménez-Flores, $\ddagger$ J. H. Walker,§ and Hamza Daroub* \\ *Nutrition and Food Sciences Department, 315 FAFS, American University of Beirut, Riad El Solh 1107 2020, Beirut, Lebanon \\ †Food Science and Nutrition Department, \\ ‡Dairy Products Technology Center, \\ §Statistics Department, California Polytechnic University, San Luis Obispo 93407
}

\begin{abstract}
The objectives of this work were to assess the compositional properties and sensory characteristics of ingredients produced by treating sweet-cream and whey-cream buttermilks with microfiltration (MF), diafiltration (DF), and supercritical $\mathrm{CO}_{2}(\mathrm{SFE})$ extraction. Sweet-cream buttermilk (CBM) and buttermilk resulting from churning the residual fat from whey processing (whey buttermilk, WBM) were used. Using MF or microfiltration followed by diafiltration (MF$\mathrm{DF}$ ), we obtained resulting retentates that were dried and then were subjected to SFE treatment. Control buttermilks, SFE resulting products, and MF and MFDF SFE and all treated retentates products totaled 16 samples ( 2 types $\times 4$ treatments $\times 2$ batches). Eleven trained panelists assessed samples using descriptive analysis. Sweet-cream buttermilk was higher in protein and lactose, whereas the WBM had similar total protein, mainly $\beta$-LG and $\alpha$-LA but very low lactose. The resulting samples in order of concentration for fat and lactose were control samples $>\mathrm{SFE}$ treated $>\mathrm{MF}$ treated $>\mathrm{DF}=\mathrm{MF}-\mathrm{SFE}$ and DF-SFE. Sodium dodecyl sulfate-PAGE protein profiling showed negligible casein for WBM versus CBM and less whey proteins for CBM versus WBM, as expected. Whey buttermilk was more yellow, salty, sour, and rancid than CBM. Regarding the treatments, significant differences were obtained on homogeneity, opacity, rancid odor, cardboard and sour flavors, sweet and salty tastes, viscosity, and mouthcoating, where SFE-treated samples showed lowest rancid odor and cardboard flavor.
\end{abstract}

\footnotetext{
Received November 20, 2014.

Accepted March 5, 2015.

${ }^{1}$ Use of names, names of ingredients, and identification of specific models of equipment is for scientific clarity and does not constitute any endorsement of product by authors, California Polytechnic State University (San Luis Obispo), the Dairy Products Technology Center, or the American University of Beirut.

${ }^{2}$ Corresponding author: ammar.olabi@aub.edu.lb
}

Key words: sensory, buttermilk, supercritical fluid extraction, whey

\section{INTRODUCTION}

The dairy industry is actively seeking value added to milk and its products. This is currently achieved by innovation and new product development. However, reducing waste or adding value to by-products in milk processing is also a very valuable strategy and central to sustainability in the industry. Aligned with these objectives, working on the development of new ingredients that contain higher concentration of milk phospholipids is beneficial, especially when these ingredients are used in studies to demonstrate their positive biological activity in human health and well-being (Ahn and Schroeder, 2002; Ward and German, 2004; Snow et al., 2010; Ahn, Ganesan et al., 2011). At the same time, a rich source of milk phospholipids in a by-product of the whey-processing industry has been identified (Astaire, Ward et al., 2003; Jinjarak et al., 2006; Jimenez-Flores and Brisson, 2008; Jiménez-Flores and Higuera-Ciapara, 2009; Costa et al., 2010).

Microfiltration (MF) has been applied to buttermilk (Astaire et al., 2003; Costa et al., 2010) and to wheycream buttermilk (Morin et al., 2006; Costa et al., 2010). Besides MF, another processing method that was used in this work is supercritical fluid extraction (SFE). Carbon dioxide $\left(\mathrm{CO}_{2}\right)$ is currently the solvent of choice (Zougagh et al., 2004; Herrero et al., 2010) in SFE that can easily reach supercritical conditions $\left(30.9^{\circ} \mathrm{C}\right.$ and $7,380 \mathrm{kPa}$ ) and has wide availability, low toxicity, low cost, and environmental friendliness and is gaseous at room temperature and pressure. The main advantage of SFE with supercritical $\mathrm{CO}_{2}$ is it being a good solvent of milk triglycerides, while at the same time not dissolving the polar lipids from milk. Supercritical $\mathrm{CO}_{2}$ has been effective in inactivating Cronobacter spp. in dehydrated powdered infant formula (Kim et al., 2010) and in the production of low-fat goat cheese that is lower in triglycerides and cholesterol while maintaining 
the beneficial phospholipids content (Sánchez-Macías et al., 2013). The polar lipids, which remain in the product, are believed to be beneficial to human health with antioxidative, anticarcinogenic, and antiatherogenic properties (Spence et al., 2009). In addition, they are widely used because of their emulsifying and structural properties in food matrices (Rombaut and Dewettinck, 2006). Moreover, the functionality of whey protein may be improved by treatment with supercritical carbon dioxide to produce new ingredients. Whey protein concentrates (Mannoi and Rizvi, 2008) and isolates (Zhong and Jin 2008) showed an improvement in gelling properties after supercritical $\mathrm{CO}_{2}$ treatment. Thus, these innovative ingredients may be used as food texturizers, emulsifiers, and rheology modifiers.

The literature on membrane processing dairy retentates includes several studies on UF, and in certain instances UF coupled with diafiltration (DF). Milk retentates were used as ingredients in formulating dairy products, including Feta cheese (de Block et al., 1996), Cheddar cheese (St-Gelais et al., 2001), and Minas Frescal cheese (Cuncha et al., 2004). On the other hand, MF milk retentate was successfully used in the making of hard cheese varieties because it enhanced the curd firmness and cheese yield (Daufin et al., 2001). Studies have been conducted on the sensory aspects of dairy powders, including skim milk powder, whole milk powder, and whey powder. Parameters such as temperature and packaging must be controlled to keep the sensory quality and to prevent off-flavors in nonfat dry milk (Driscoll et al., 1985; Karagül-Yüceer et al., 2002). Karagül-Yüceer et al. (2004) stated that cooked and sweet aroma were the key attributes in nonfat dry milk and were noted in higher intensity than in fluid skim milk (Drake et al., 2003; Karagül-Yüceer et al., 2004). The authors added that these compounds could help indicate the flavor changes due to processing and storage effects (Karagül-Yüceer et al., 2004). Composition also influenced flavor because flavors found in skim milk powder were not noted in whole milk powder (Drake et al., 2003). In addition, cardboard flavor was present in the whey protein concentrates. Studies have been conducted on the physicochemical properties of $\mathrm{MF}$ and SFE-treated dairy ingredients. However, the literature on the sensory evaluation of these products is very scarce, especially given the potential of these products in terms of functionality and health benefits. The objectives of this work were to assess the compositional properties and sensory characteristics of ingredients produced from treating sweet-cream and whey-cream (an underused by-product) buttermilks with MF, diafiltration (MF-DF), and supercritical $\mathrm{CO}_{2}$ (SFE) extraction.

\section{MATERIALS AND METHODS}

\section{Treatments}

Buttermilk Manufacture. Sweet cream and whey cream were provided by Foster Farms (Modesto, CA) and Hilmar Cheese Company (Hilmar, CA). Samples consisted of two 500-L batches of sweet-cream buttermilk and two 500-L batches of whey buttermilk. The buttermilks were produced at the Dairy Products Technology Center (DPTC) at California Polytechnic State University, San Luis Obispo. They were churned after a waiting period of $16 \mathrm{~h}$ at $4^{\circ} \mathrm{C}$. Sweet cream was churned to butter using a continuous pilot scale butter churn (Egli AG, Bütschwil, Switzerland). Buttermilk was recovered after butter fines were removed by filtration through cheese cloth, then spray dried using a Niro Filterlab Spray Drier (Hudson, WI). The buttermilk production on site at DPTC was repeated 2 times, with 2 different lots of the 2 creams. The whey buttermilk was produced as described by Costa et al. (2010).

Processing. All buttermilks were spray dried at DPTC and used in the spray-dried powder form. The samples were subjected to SFE treatment as described by Astaire et al. (2003). In addition, liquid batches for each sample were exposed to MF or MF-DF, and the resulting retentates were dried and then subjected to SFE treatment. Buttermilk powder was subjected to MF and, for certain treatments, MF-DF as described by Astaire et al. (2003) but using a $0.1-\mu \mathrm{m}$ ceramic membrane (GEA filtration, Hudson, WI). The diafiltration used in this study was the batch mode. In this system, stages were performed consecutively, and then diafiltration liquid (water) was added into the tank after the preconcentration. Microfiltration then followed the diafiltration until the desired concentration was reached in the retentates. In addition, the buttermilk, MF-retentate, and MF-DF-retentate powders were exposed to SFE as described by Astaire et al. (2003). The samples were treated with a combination of MF $[\mathrm{MF}$ $(2 \times \mathrm{vol} / \mathrm{vol})$ and SFE] or DF [MF-DF $(2 \times \mathrm{vol} / \mathrm{vol})$ and SFE]. Buttermilk samples were also treated with only SFE. The DF and MF had 0.1- $\mu \mathrm{m}$ membrane pore size and were operated at cold temperature $\left(10^{\circ} \mathrm{C}\right)$. Samples were reconstituted. The SFE parameters were set at $35 \mathrm{MPa}$ for pressure and $50^{\circ} \mathrm{C}$ at a $20 \mathrm{~g} / \mathrm{min}$ flow rate and had 3 vessel flushes that ran a time equal to 75 min. The control buttermilks, SFE-resulting products, and the MF and DF SFE-treated retentates were used, which meant that 4 different treatments existed for these samples. Accordingly, the total number of samples was 16 (2 experimental types $\times 4$ treatments $\times 2$ batches). 
Storage. Samples were kept in sealed plastic bags and in cardboard boxes inside a ventilated room at $10^{\circ} \mathrm{C}$ before reconstitution for sensory evaluation. Samples used for the experiments were less than 6 mo old.

\section{Chemical Analyses}

Fat content was determined by the Mojonnier ether extraction method using $1 \mathrm{~g}$ of powder (AOAC International, 1996, method number 33.2.26; 989.05). Protein content was determined by Kjeldahl method using $0.5 \mathrm{~g}$ of powder (AOAC International, 1996, method number 33.2.11; 991.20). Total solids content was determined by direct forced-air oven drying at $100^{\circ} \mathrm{C}$ for $4 \mathrm{~h}$, and ash was determined by putting samples in the muffler incinerator at $550^{\circ} \mathrm{C}$ (AOAC International, 1996, method number 33.2.44; 990.20). Lactose content was calculated by the difference on a DM basis of $100-$ (protein + fat + ash).

\section{Protein Profiling by SDS-PAGE}

Protein profiling was conducted as described by Costa et al. (2010). Samples were diluted with deionized water to yield $3 \%$ protein solution and diluted with reducing-denaturing buffer at 1:20 dilution. Samples were boiled for $10 \mathrm{~min}$, and then $20 \mu \mathrm{g}$ of samples were loaded in the $10 \%$ acrylamide gel and ran at $95 \mathrm{~V}$ through stacking gel and $110 \mathrm{~V}$ through resolving gel. Ten micrograms of Precision Plus Protein Standards, unstained (Bio-Rad, Hercules, CA, catalog \#161-0363), was the molecular-weight standard. Gels were stained using Coomassie Brilliant Blue R-250 Staining Solution (Bio-Rad, catalog \#161-0436) overnight and unstained the following day with normal destained solution.

\section{Descriptive Analysis}

Training. Eleven panelists (all females, ages from 24 to $45 \mathrm{yr}$ ), who were students and staff at California Polytechnic State University, San Luis Obispo, were trained over nine 1-h sessions for $5 \mathrm{wk}$. The SFE-treated commercial buttermilks and SFE-treated DPTC samples reconstituted from powders were used during training, as well as some of the experimental buttermilks. The training included tasting different reconstituted liquid samples and discussing their characteristics. The panelists generated 25 attributes and definitions in the training sessions, along with reference standards for several of the attributes (Table 1). For the purpose of the descriptive terminology used in this work, "odor" refers to the specific odor perceived when smelling the sample with the nostrils and "flavor" refers to the odor or aroma that is perceived retronasally when the sample is in the mouth.
Evaluation. During the evaluation period, the panelists attended 8 sessions (one morning and one afternoon session each day) for a 4-d period. Four samples were served at each session. The order of the samples was randomized for the panelists over every 2-d period, which corresponded to a replicate. There were 2 replicate evaluations (one per $2 \mathrm{~d}$ ), with all 16 samples $(2$ experimental types $\times 4$ treatments $\times 2$ batches) served within each replicate. Samples reconstituted from powder were freshly mixed each day 1 to $2 \mathrm{~h}$ before serving based on a final protein concentration of $3 \%$, which was calculated based on initial protein concentration. Samples were first prepared and then kept in a $5^{\circ} \mathrm{C}$ refrigerator until $30 \mathrm{~min}$ before serving, when samples were placed at room temperature to temper. Cups were also covered with plastic lids to preserve the odor of samples. Samples $(50 \mathrm{~mL})$ were given to panelists monadically in 148-mL plastic cups (Tumblers, Waddington North America Inc., City of Industry, CA), labeled with 3-digit numbers. Standard references were given to panelists, who rinsed their mouths with spring water before evaluating each sample and expectorated all water and samples afterward. Spoons were also given to panelists for stirring the samples before evaluation. Attributes were rated on a $15-\mathrm{cm}$ line scale score sheets. Judges were compensated with gift certificates for local stores of their choice.

\section{Statistical Analysis}

Data related to chemical and sensory analyses were analyzed using the Proc Mixed procedure of SAS (version 8.02, 1999-2001, SAS Institute Inc., Cary, NC). An ANOVA was performed to evaluate the effects of panelist, treatment, type, and replicate and their interactions. The model involved the comparison of the 2 experimental buttermilks [sweet-cream buttermilk (CBM) and whey buttermilk (WBM)] with their SFE-treated resulting products as well as their SFEtreated MF and MF-DF retentates. Significant means for the sensory analyses were separated by Tukey's honestly significant difference method with $\alpha=0.05$.

\section{RESULTS AND DISCUSSION}

\section{Chemical Analyses}

Comparisons were made between the types of buttermilks (CBM vs. WBM) and between the 4 different treatments of CBM and WBM, specifically the control buttermilk, SFE-treated buttermilk, and MF and MFDF buttermilk derived products as illustrated in Figures 1 to 3 . Buttermilk types $(P<0.05$; Figure 1$)$ and treatments $(P<0.01$; Figures 2 and 3$)$ significantly 
Table 1. List of attributes and reference standards for descriptive analysis for treated buttermilk-based ingredients

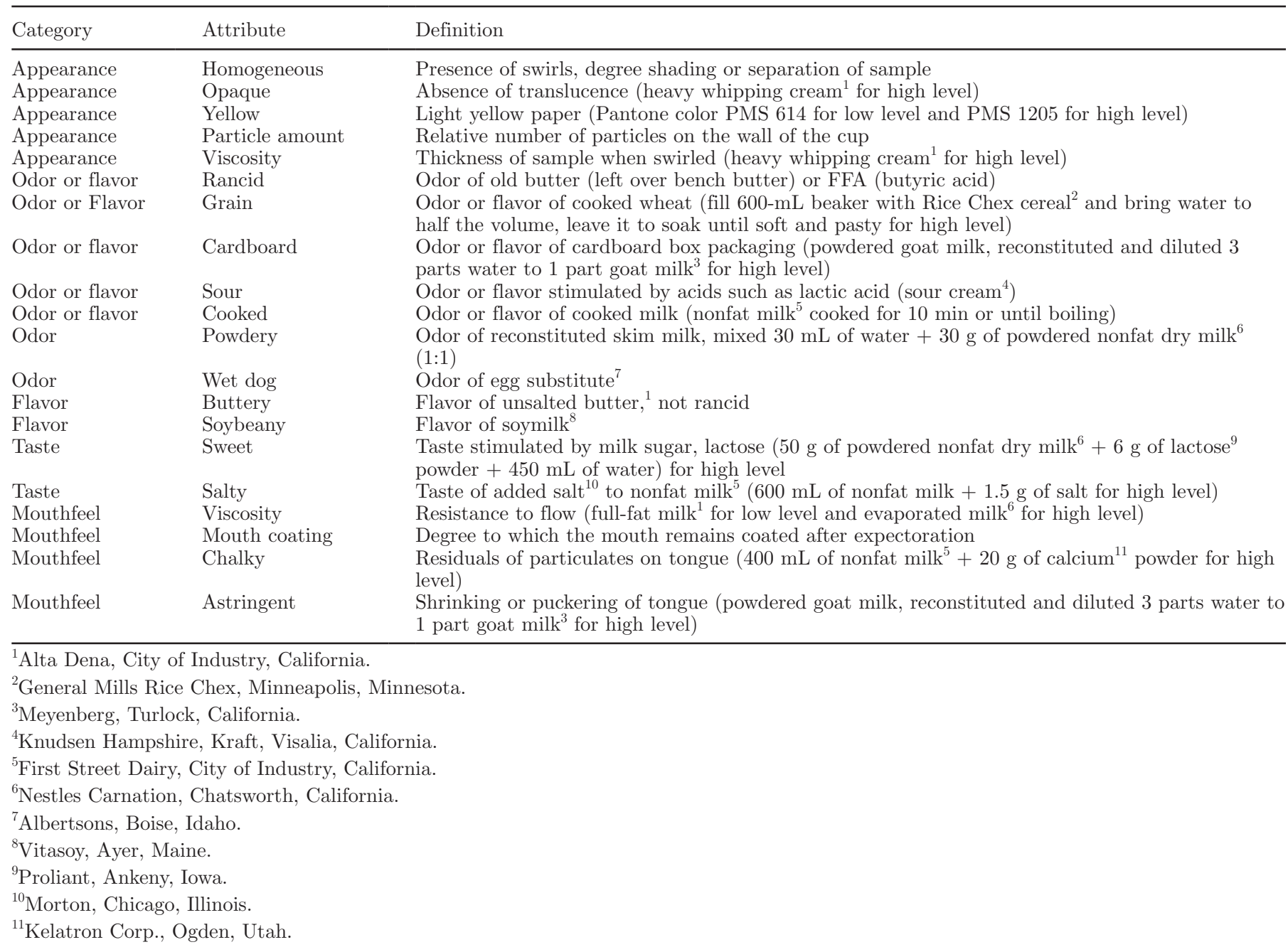

differed in lactose and protein contents. The WBM treatments also significantly differed in fat $(P<0.01)$.

A look at the means for each combination of type and treatment (Figures 2 and 3) revealed that for every treatment level, CBM had significantly higher $(P<$ $0.05)$ protein content compared with WBM, with the WBM protein content roughly half the CBM one. The WBM had a higher lactose content than CBM. The significant difference in protein content was due to the lack of casein in the whey cream as compared with sweet cream and has been reported in previous studies (Morin et al., 2006; Sodini et al., 2006). It should be noted that in the study by Sodini et al. (2006), the level of protein in whey buttermilk was very similar to that observed in whey (13\%), which is consistent with the expectations of whey buttermilk resembling whey composition as opposed to control buttermilk, which resembles skim milk in composition. The higher lactose content for WBM was also obtained in the study by
Sodini et al. (2006) and was reciprocal to the protein levels. In both CBM and WBM, the highest protein content was obtained for the MF-DF SFE sample. The lowest protein content in both types of buttermilk occurred in the SFE and control samples, with no significant difference between them.

As for the fat content for the WBM samples, it was also significantly higher $(P<0.05)$ for MF-DF SFE than the other treatments. Although the fat content of the SFE treatment was not significantly different from the control buttermilk and MF-SFE treatments, its level was very low with only 2.30 versus 9.69 and 10.79 for SFE, MF-SFE, and control, respectively. The lower fat content in the SFE treatment is due to the removal of triglycerides (Astaire et al., 2003; Spence et al., 2009). These ingredients enhance the emulsifying properties of dairy products because of their higher content in phospholipids (Costa et al., 2010), which makes them ideal for ice cream applications. Similar products were 


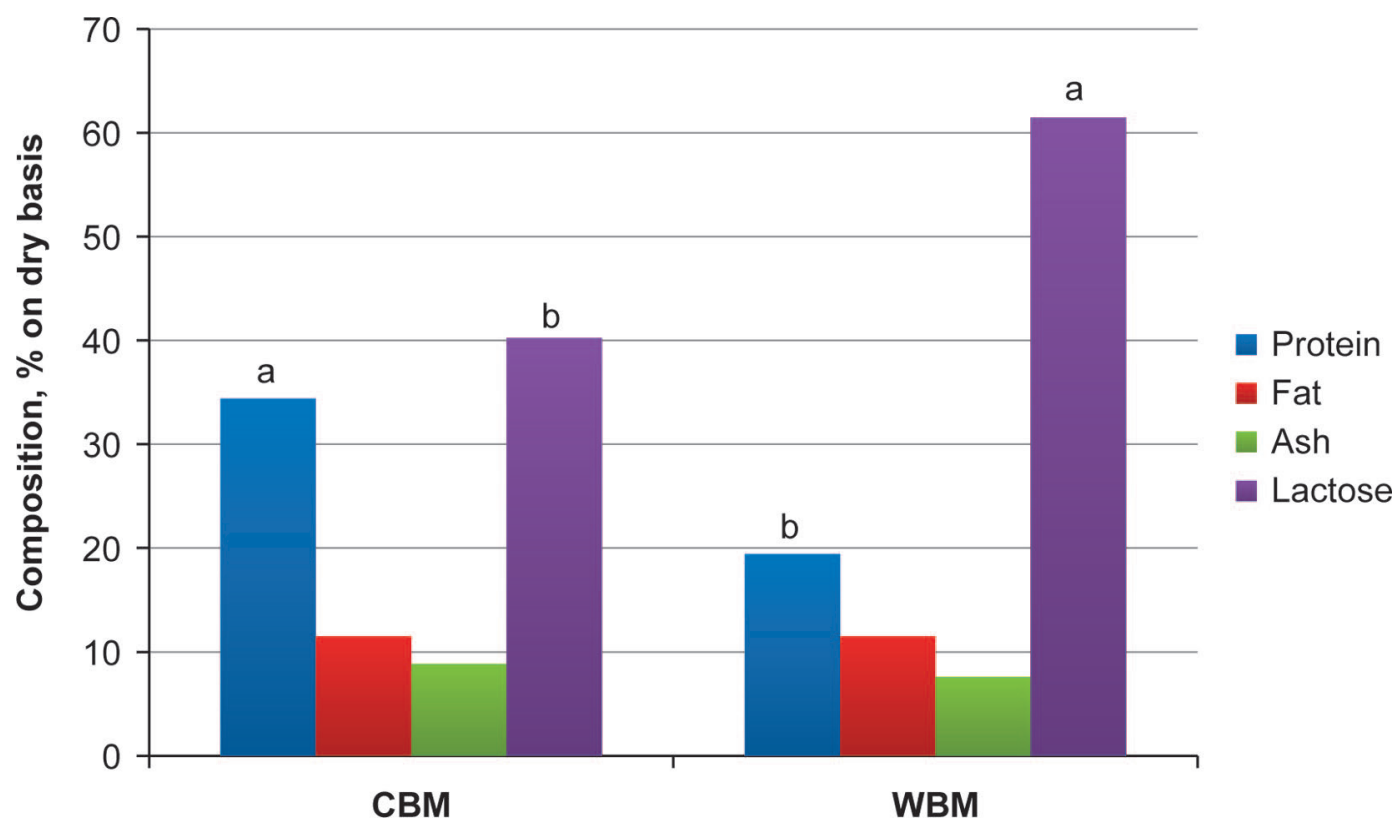

Figure 1. Composition of sweet-cream buttermilk (CBM) compared with whey buttermilk (WBM) for protein, fat, ash, and lactose on a dry basis. Means within the same type of chemical variable with different letters (a,b) are significantly different $(P<0.05)$.

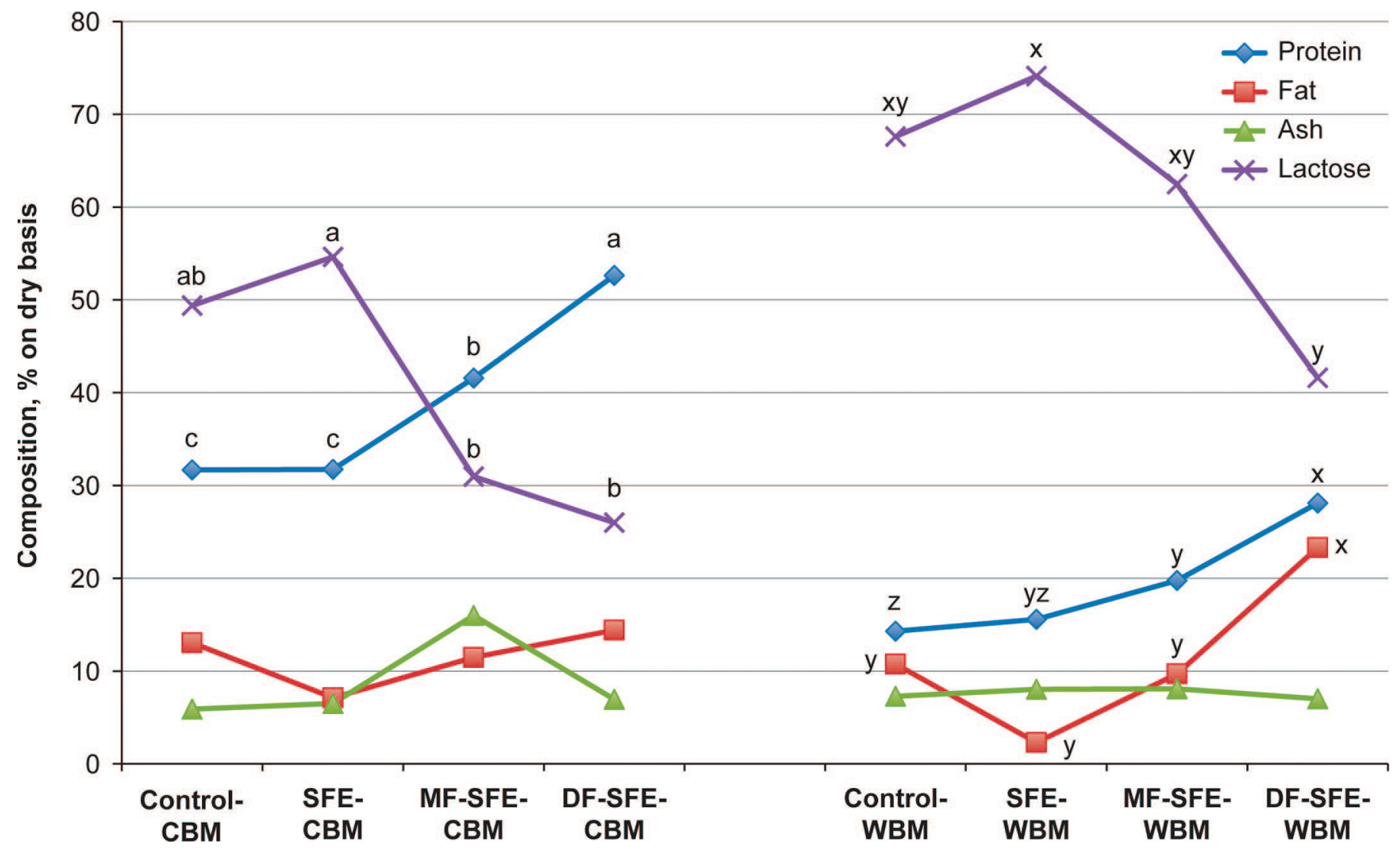

Figure 2. Composition of control; supercritical fluid extraction (SFE); microfiltration SFE (MF SFE); and microfiltration, followed by diafiltration, followed by SFE (MF-DF SFE) treatments for sweet-cream (CBM) and whey-cream (WBM) buttermilks for protein, fat, ash, and lactose on a dry basis. Means within the same type of chemical variable with different letters $(\mathrm{a}-\mathrm{c})$ are significantly different $(P<0.05)$; means within the same type of chemical variable with different letters $(\mathrm{x}-\mathrm{z})$ are significantly different $(P<0.05)$. 


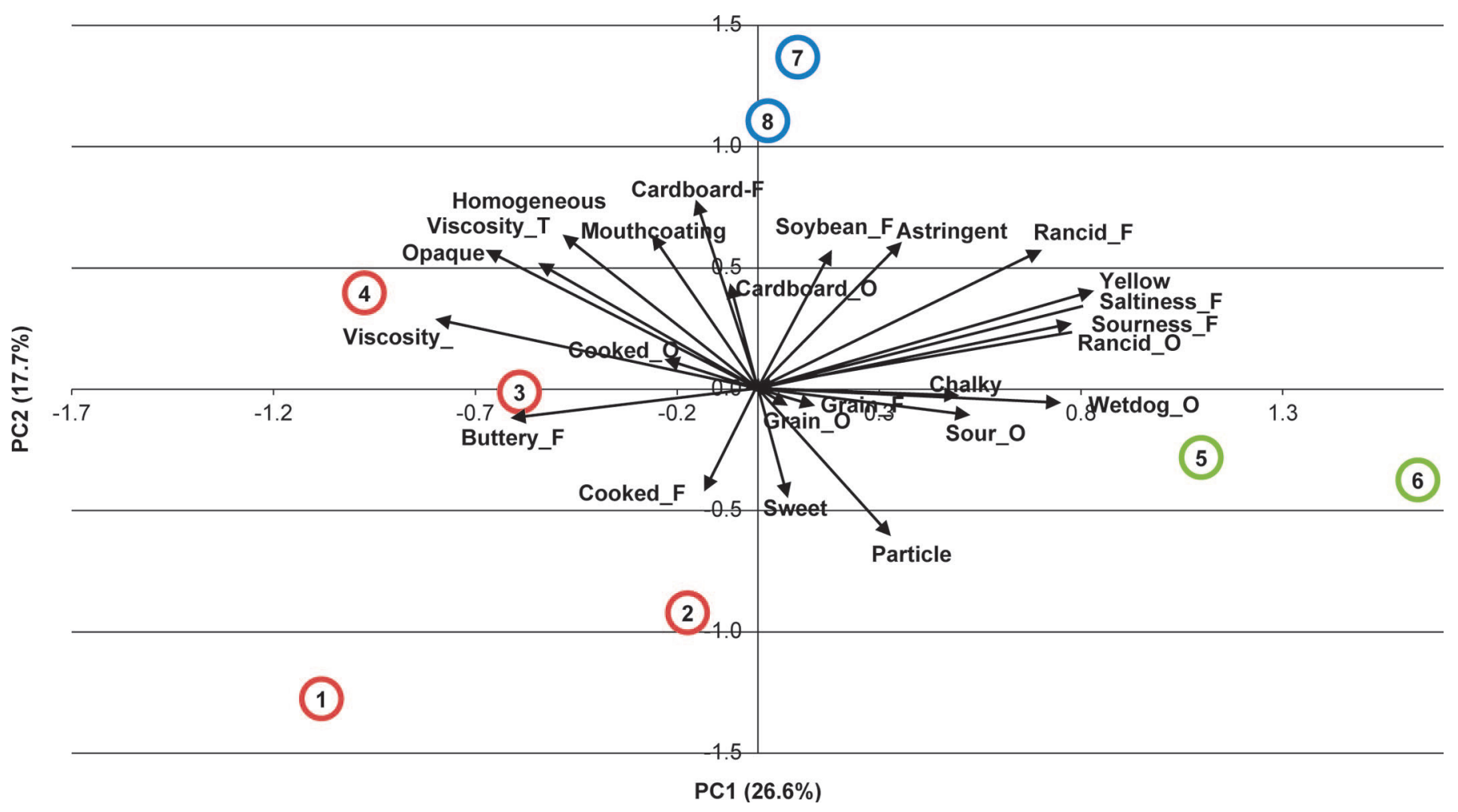

Figure 3. Principal component $(\mathrm{PC})$ analysis plot of samples and attributes. $\mathrm{A}=$ appearance, $\mathrm{T}=$ texture, $\mathrm{O}=$ odor, $\mathrm{F}=$ flavor. Sample 1 $=$ control CBM, sample $2=\mathrm{SFE}$ CBM, sample $3=\mathrm{MF}$ SFE CBM, sample $4=\mathrm{MF}-\mathrm{DF}$ SFE CBM, sample $5=$ control WBM, sample $6=\mathrm{SFE}$ WBM, sample $7=$ MF SFE WBM, sample $8=$ MF-DF SFE WBM. SFE = supercritical fluid extraction; MF SFE = microfiltration followed by SFE; MF-DF SFE = microfiltration, followed by diafiltration, followed by SFE; CBM = sweet-cream buttermilk; WBM = whey buttermilk.

used in Denmark as thickeners. The functionality of these ingredients is due to the large number of particles that contribute to viscosity rather than the size of these particles (Saffon et al., 2014).

The lactose levels were not significantly different between the control buttermilk and SFE treatments, although a higher level was noted in the SFE because of the concentration effect for the nonfat solids as a result of nonpolar fat removal. However, treatments MF SFE and MF-DF SFE were significantly lower $(P<0.05)$ than the SFE, except for the MF SFE for the WBM samples, because of the removal of lactose in MF and the more efficient removal with DF.

\section{Protein Profiling by SDS-PAGE}

The SDS-PAGE gels showed negligible casein content for the WBM samples compared with the CBM ones, which was due to the fact that most casein already was extracted in cheese curd, leaving whey proteins in the drained whey and ultimately in the whey cream (Spence et al., 2009; Costa et al., 2010). The SFE treatment removed the nonpolar lipids in particular; hence, not much of an effect was noted with the protein profile.
On the other hand, the WBM treatments had thicker bands for the whey proteins, especially for $\beta-L F$, than the CBM ones. This is an expected outcome because most of the whey proteins were drained with the whey during cheesemaking as noted above. In addition, the whey proteins were present in higher quantities in the regular buttermilk and SFE WBM treatments versus the MF-SFE and MF-DF SFE WBM ones because of losses in the MF and MF-DF process. This is again an expected outcome due to the decrease of whey proteins in the microfiltration retentate (Costa et al., 2010).

\section{Sensory Descriptive Analysis}

The means of attributes affected by either buttermilk type or treatment alone are described in Table 2. Attributes with interaction effects are described in Table 3.

The WBM was significantly $(P<0.05)$ more yellow and had more rancid flavor across all treatments (Table 2 ). The higher yellow color for WBM is due to the color of whey cream, which is influenced by the addition of annatto from cheesemaking. Rancid off-flavors can occur not only due to lipolysis, but also due to proteolysis (Lee and Morr, 1994). The WBM also had significantly 
Table 2. Least squares means scores (on a 15-cm line scale) of descriptive analysis of attributes for treated buttermilk-based ingredient samples

\begin{tabular}{|c|c|c|c|c|c|c|}
\hline Item & \multicolumn{2}{|c|}{ Type $^{1}$} & \multicolumn{4}{|c|}{ Treatment $^{2}$} \\
\hline Yellow & $6.46^{\mathrm{b}}$ & $13.80^{\mathrm{a}}$ & 9.39 & 11.10 & 10.22 & 9.80 \\
\hline Opaque & 7.00 & 6.87 & $6.93^{\mathrm{ab}}$ & $4.75^{\mathrm{b}}$ & $7.63^{\mathrm{ab}}$ & $8.44^{\mathrm{a}}$ \\
\hline Particle & 9.83 & 9.27 & 12.13 & 11.37 & 5.76 & 8.96 \\
\hline Viscosity & 7.11 & 5.86 & 6.70 & 4.67 & 7.01 & 7.57 \\
\hline Sour odor & 3.22 & 3.52 & 3.33 & 4.00 & 3.30 & 2.87 \\
\hline Grain odor & $3.71^{*}$ & $3.49^{*}$ & $3.87^{*}$ & $3.72^{*}$ & $3.44^{*}$ & $3.37^{*}$ \\
\hline Cooked odor & 5.28 & 5.02 & 5.27 & 4.87 & 5.59 & 4.87 \\
\hline Powdery odor & 5.76 & 5.36 & 5.49 & 5.49 & 5.92 & 5.34 \\
\hline Wet dog odor & 3.62 & 4.49 & 3.64 & 5.00 & 3.81 & 3.76 \\
\hline Cardboard flavor & 6.80 & 7.33 & $6.07^{\mathrm{b}}$ & $6.57^{\mathrm{b}}$ & $7.71^{\mathrm{ab}}$ & $7.93^{\mathrm{a}}$ \\
\hline Sweet taste & $4.55^{*}$ & $4.41^{*}$ & $5.36^{*}$ & $5.27^{*}$ & $4.51^{*}$ & $2.78^{*}$ \\
\hline Rancid flavor & $3.54^{\mathrm{b}}$ & $5.83^{\mathrm{a}}$ & 3.95 & 4.83 & 4.70 & 5.26 \\
\hline Salty taste & $1.85^{*}$ & $7.91^{*}$ & $5.22 *$ & $5.70^{*}$ & $5.36^{*}$ & $3.24^{*}$ \\
\hline Viscosity & 6.48 & 5.57 & $4.76^{\mathrm{b}}$ & $5.20^{\mathrm{ab}}$ & $6.66^{\mathrm{ab}}$ & $7.49^{\mathrm{a}}$ \\
\hline Chalky & 6.05 & 7.36 & 7.37 & 6.91 & 5.47 & 7.08 \\
\hline Astringent & 4.71 & 6.09 & 5.21 & 5.30 & 5.71 & 5.37 \\
\hline Mouthcoating & 7.06 & 7.33 & $6.89^{\mathrm{ab}}$ & $6.07^{\mathrm{b}}$ & $7.38^{\mathrm{ab}}$ & $8.45^{\mathrm{a}}$ \\
\hline
\end{tabular}

${ }^{a-d}$ Means within a row with different superscripts are significantly different $(P<0.05)$.

${ }^{1} \mathrm{CBM}=$ sweet-cream buttermilk; WBM $=$ whey buttermilk.

${ }^{2} \mathrm{SFE}=$ supercritical fluid extraction; MF SFE = microfiltration followed by SFE; MF-DF SFE = microfiltration, followed by diafiltration, followed by SFE.

$*$ Attributes with significant type $\times$ treatment interaction.

$(P<0.05)$ more salty flavor than CBM across all treatments (Table 3), although the size of the difference varied from treatment to treatment. The WBM had more sour flavor (Table 3) than CBM in all treatments except MF-DF SFE, in which no difference could be detected. Rancid odor and flavor are usually the product of lipolysis of FFA (Lawless and Claassen, 1993). Free fatty acids were also a major cause for volatile compounds in nonfat dry milk (Karagül-Yüceer et al., 2002). The significantly higher sourness and saltiness in WBM under some of the treatments is probably due to remnants of lactic acid and salt in the whey cream. The attributes noted in the samples of this work such as cooked, chalky, acidic, and salty were also found in reconstituted whole milk (Hough et al., 1992). The sweet flavor and buttery aroma were the result of the 2,3-butandione, whereas hydrogen sulfide contributed to cooked odor and flavor (Hall and Andersson, 1985).

Sweet flavor did not significantly differ for either WBM or CBM under any of the treatments (Table 3);

Table 3. Least squares means scores (on a 15-cm line scale) of attributes with significant type $\times$ treatment interaction for treated buttermilkbased ingredient samples in Table $2^{1}$

\begin{tabular}{|c|c|c|c|c|c|c|c|c|}
\hline Item & \multicolumn{2}{|c|}{ Control } & \multicolumn{2}{|c|}{$\mathrm{SFE}$} & \multicolumn{2}{|c|}{ MF SFE } & \multicolumn{2}{|c|}{ MF-DF SFE } \\
\hline Rancid odor & $2.89^{\mathrm{d}}$ & $5.73^{\mathrm{abc}}$ & $5.33^{\mathrm{abc}}$ & $6.56^{\mathrm{a}}$ & $4.28^{\mathrm{bcd}}$ & $4.86^{\mathrm{abcd}}$ & $3.96^{\mathrm{cd}}$ & $6.27^{\mathrm{ab}}$ \\
\hline Sweet taste & $6.08^{\mathrm{a}}$ & $4.63^{\mathrm{ab}}$ & $5.97^{\mathrm{a}}$ & $4.58^{\mathrm{ab}}$ & $3.79^{\mathrm{ab}}$ & $5.23^{\mathrm{ab}}$ & $2.35^{\mathrm{b}}$ & $3.20^{\mathrm{ab}}$ \\
\hline Cooked flavor & $6.58^{\mathrm{a}}$ & $5.09^{\mathrm{a}}$ & $6.60^{\mathrm{a}}$ & $5.49^{\mathrm{a}}$ & $5.48^{\mathrm{a}}$ & $6.42^{\mathrm{a}}$ & $4.64^{\mathrm{a}}$ & $5.35^{\mathrm{a}}$ \\
\hline Sour & $1.54^{\mathrm{b}}$ & $4.96^{\mathrm{a}}$ & $1.61^{\mathrm{b}}$ & $5.00^{\mathrm{a}}$ & $1.56^{\mathrm{b}}$ & $4.85^{\mathrm{a}}$ & $1.71^{\mathrm{b}}$ & $2.39^{\mathrm{b}}$ \\
\hline
\end{tabular}

${ }^{\mathrm{a}-\mathrm{d}}$ Means within a row with different superscripts are significantly different $(P<0.05)$.

${ }^{1} \mathrm{SFE}=$ supercritical fluid extraction; MF SFE = microfiltration followed by SFE; MF-DF SFE = microfiltration, followed by diafiltration, followed by SFE; CBM = sweet-cream buttermilk; WBM = whey buttermilk. 
however, lactose could contribute to Maillard browning by reacting with amino acids. The WBM had higher lactose than CBM, which could possibly enhance the yellow color in WBM. Walstra et al. (1999) noted that other than brown color, off-flavors were produced and loss of nutrients occurred, which explained several unwanted attributes in WBM. Whey proteins, in addition to calcium phosphate and caseins, can interact during heat treatment of milk powder and result in astringency. Heat treatment, for instance, during spray drying could have contributed to the partial denaturation of protein (Damodaran, 1996). However, no significant differences in astringency between CBM and WBM were obtained in this work.

In terms of the differences between the 4 treatments (control buttermilks, SFE-treated buttermilks, and SFE-treated buttermilk derived MF and MF-DF retentates), a lack of homogeneity could be problematic for consumer acceptance. The only difference in homogeneity detected between the 4 treatments was that MF SFE was more homogenous than SFE. Viscous appearance has been found to be the result of low solubility due to denatured proteins aggregating from the protein cross-linking (Damodaran, 2007). According to the mean scores for each treatment (Table 2), MF-DF SFE was more opaque and had more mouthcoating than the SFE-treated samples and was more viscous than the nontreated samples. The MF-DF SFE treatment also had more cardboard flavor than both the SFE-treated and nontreated samples. Cardboard flavor, attributed to lipid oxidation products, is a common attribute of many dried dairy ingredients (Drake et al., 2003).

For some attributes, the effect of the treatment differed depending on the type of buttermilk. The means for these attributes are shown in Table 3. For WBM, the MF-DF SFE was the least salty and sour, probably due to the effect of DF on removing any highly aqueous solutes such as sodium chloride and lactic acid; however, for CBM no differences in salty or sour flavor were detected between the treatments. In addition, sweetness was higher for the SFE-treated and the nontreated samples than in the MF-DF SFE treated samples, but only for CBM. The SFE-treated samples had more rancid odor than the nontreated in CBM but not in WBM.

\section{Principal Components Analysis}

Results of the principal component (PC) analysis are illustrated in Figure 3. Principal component 1 explained $26.6 \%$ and PC2 $17.7 \%$ of variation (44.2\% for both). Principal component 1 divided samples based on type of buttermilk (CBM vs. WBM). The left side of PC1 was characterized by the texture attributes, opaque appearance, mouthcoating, cooked odor and flavor, in addition to buttery flavor. Cooked and buttery flavors are usually associated with dairy powders and tend to be conducive to high consumer acceptability. All CBM treatment samples fell in this area. The positive side of PC1 includes yellow, particle, chalky, soybean flavor, grain, sour and rancid odors and flavors, saltiness, sweetness, and astringency. The positive side of $\mathrm{PC} 1$ included the WBM samples (samples 5-8), although the WBM retentates (samples 7 and 8) were almost in the middle of the scale. The WBM retentates had high scores for cardboard odor and flavor, which was the opposite for sample 2 (CBM-SFE), and to a certain extent sample 1 (CBM), which were characterized by cooked flavor, sweetness, and buttery flavor that are more typical of dairy powders. The higher yellow color, sourness, and astringency of samples 5 and 6 (control buttermilk and SFE-treated WBM) was noted (Jinjarak et al., 2006) when comparing sensory profiles of sweetcream and whey buttermilks. Principal components 2 divided samples based on processing, with the negative side having control buttermilk and SFE-treated CBM (samples 1 and 2) and WBM (samples 5 and 6), and the positive side had the retentates for CBM (samples 3 and 4) and WBM (samples 7 and 8).

\section{CONCLUSIONS}

Significant differences were noted between CBM and WBM for protein, which was higher for CBM; however, lactose content was higher in WBM. Given the minimal effect on sensory properties that SFE treatment had on the CBM and WBM samples, we can state that the SFE-treated product, which has only half the fat content, could be used as a substitute for normal fat buttermilk in food applications, especially if consumer studies of the ingredients alone and incorporated into food products confirm this expectation. Additional work needs to be performed, especially on the nutritional profile of the SFE-treated products, mostly with respect to minor biologically active components. In addition, cell culture work with SFE-treated products that are high in these biologically active components could assess the effect of these components on atherosclerosis and cancer.

\section{ACKNOWLEDGMENTS}

The funding by the Agricultural Research Initiative (California State University, San Luis Obispo), Dairy Management Inc. (Rosemont, IL), California Dairy Research Foundation (Davis, CA), and the Hilmar Cheese Company (Hilmar, CA) is gratefully acknowledged. The authors thank Pierre Morin (Laval University, Quebec 
City, Canada) for his technical assistance and all the panelists for their dedication.

\section{REFERENCES}

Ahn, E. H., and J. J. Schroeder. 2002. Bioactive sphingolipids are constituents of soy and dairy products. J. Food Sci. 67:522-524.

Ahn, Y. J., P. Ganesan, and H.-S. Kwak. 2011. Composition, structure, and bioactive components in milk fat globule membrane. Korean J. Food Sci. Anim. Resour. 31:1-8.

AOAC International. 1996. Official Methods of Analysis. AOAC Int., Gaithersburg, MD.

Astaire, J. C., R. Ward, J. B. German, and R. Jiménez-Flores. 2003 Concentration of polar MFGM lipids from buttermilk by microfiltration and supercritical fluid extraction. J. Dairy Sci. 86:22972307.

Costa, M. R., X. E. Elias-Argote, R. Jiménez-Flores, and M. Lúcia Gigante. 2010. Use of ultrafiltration and supercritical fluid extraction to obtain a whey buttermilk powder enriched in milk fat globule membrane phospholipids. Int. Dairy J. 20:598-602.

Cuncha, C. R., L. A. Viotto, and W. H. Viotto. 2004. Use of low concentration factor ultrafiltration retentates in reduced-fat Minas Frescal cheese manufacture: Effect on yield and sensory properties. Int. J. Dairy Technol. 57:231-236.

Damodaran, S. 2007. Amino acids, peptides, and proteins. Pages 217330 in Fennema's Food Chemistry. 4th ed. S. Damodaran. K. L. Parkin, and O. R. Fennema, ed. CRC Press/Taylor and Francis Group, Boca Raton, FL.

Daufin, G., J.-P. Escudier, H. Carrére, S. Bérot, L. Fillaudeau, and M. Decloux. 2001. Recent and emerging applications of membrane processes in the food and dairy industry. Food Bioprod. Process. 79:89-102.

de Block, J., W. de Ville, and L. Petit. 1996. Manufacture of a feta cheese using skim milk retentate powder. J. Soc. Dairy Technol. 49:37-49.

Drake, M. A., Y. Karagul-Yuceer, K. R. Cadwallader, G. V. Civille, and P. S. Tong. 2003. Determination of the sensory attributes of dried milk powders and dairy ingredients. J. Sens. Stud. 18:199216.

Driscoll, N. R., C. P. Brennand, and D. G. Hendricks. 1985. Sensory quality of nonfat dry milk after long-term storage. J. Dairy Sci. 68:1931-1935.

Hall, G., and J. Andersson. 1985. Flavor changes in whole milk powder during storage. Relationships between flavor properties and volatile compounds. J. Food Qual. 7:237-253.

Herrero, M., J. A. Mendiola, A. Cifuentes, and E. Ibáňez. 2010. Supercritical fluid extraction: Recent advances and applications. J. Chromatogr. A 1217:2495-2511.

Hough, G., E. Martinez, and T. Barbieri. 1992. Sensory thresholds of flavor defects in reconstituted whole milk powder. J. Dairy Sci. $75: 2370-2374$.

Jimenez-Flores, R., and G. Brisson. 2008. The milk fat globule membrane as an ingredient: Why, how, when? Dairy Sci. Technol. 88:5-18.

Jiménez-Flores, R., and I. Higuera-Ciapara. 2009. Beverages based on milk fat globule membrane (MFGM) and other novel concepts for dairy-based functional beverages. Pages 281-296 in Functional and Specialty Beverage Technology. P. Paquin, ed. CRC Press, Woodhead Publ Limit., New York, NY.

Jinjarak, S., A. Olabi, R. Jimenez-Flores, I. Sodini, and J. H. Walker. 2006. Sensory evaluation of whey and sweet cream buttermilk. J. Dairy Sci. 89:2441-2450.
Karagül-Yüceer, Y., K. R. Cadwallader, and M. Drake. 2002. Volatile flavor compounds of stored nonfat dry milk. J. Agric. Food Chem. 50:305-312.

Karagül-Yüceer, Y., M. A. Drake, and K. R. Cadwallader. 2004. Evaluation of the character impact odorants in skim milk powder by sensory studies on model mixtures. J. Sens. Stud. 19:1-13.

Kim, S. A., O. Y. Kim, and M. S. Rhee. 2010. Direct application of supercritical carbon dioxide for the reduction of Cronobacter spp. (Enterobacter sakazakii) in end products of dehydrated powdered infant formula. J. Dairy Sci. 93:1854-1860.

Lawless, H. T., and M. R. Claassen. 1993. Validity of descriptive and defect-oriented terminology systems for sensory analysis of fluid milk. J. Food Sci. 58:108-113.

Lee, Y. B., and C. V. Morr. 1994. Lipids in food flavors: Changes in the headspace volatile compounds due to oxidation of milk fat during storage of dried dairy products. Ser. No. 558 in ACS Symp. Am. Chem. Soc., Washington, DC.

Manoi, K., and S. S. H. Rizvi. 2008. Rheological characterization of texturized whey protein concentrate-based powders produced by reactive supercritical fluid extrusion. Food Res. Int. 41:786-796.

Morin, P., R. Jiménez-Flores, and Y. Pouliot. 2006. A comparative study of the fractionation of regular buttermilk and whey buttermilk by microfiltration. J. Food Eng. 77:521-528.

Rombaut, R., and K. Dewettinck. 2006. Properties, analysis and purification of milk polar lipids. Int. Dairy J. 16:1362-1373.

Saffon, M., R. Jiménez-Flores, M. Britten, and Y. Pouliot. 2014. On the use of buttermilk components as aggregation nuclei during the heat-induced denaturation of whey proteins. J. Food Eng. $132: 21-28$.

Sánchez-Macías, D., A. Laubscher, N. Castro, A. Argüello, and R. Jiménez-Flores. 2013. Effects of supercritical fluid extraction pressure on chemical composition, microbial population, polar lipid profile, and microstructure of goat cheese. J. Dairy Sci. 96:13251334

Snow, D. R., R. Jimenez-Flores, R. E. Ward, J. Cambell, M. J. Young, I. Nemere, and K. J. Hintze. 2010. Dietary milk fat globule membrane reduces the incidence of aberrant crypt foci in Fischer-344 rats. J. Agric. Food Chem. 58:2157-2163.

Sodini, I., P. Morin, A. Olabi, and R. Jiménez-Flores. 2006. Compositional and functional properties of buttermilk: A comparison between sweet, sour, and whey buttermilk. J. Dairy Sci. 89:525-536.

Spence, A. J., R. Jimenez-Flores, L. Goddik, and M. Quian. 2009. Phospholipid enrichment in sweet and whey cream buttermilk powders using supercritical fluid extraction. J. Dairy Sci. 92:2373-2381.

St-Gelais, D., J. Fortin, and S. Haché. 2001. Effect of different ultrafiltered milk retentate powders on the production of cheddar cheese. Milchwissenschaft 56:437-440.

Walstra, P., T. J. Geurts, A. Noomen, A. Jellema, and M. A. J. S. van Boekel. 1999. Dairy Technology. Principles of Milk Properties and Processes. 1st ed. Marcel Dekker Inc., New York, NY.

Ward, R. E., and J. B. German. 2004. Understanding milk's bioactive components: A goal for the genomics toolbox. J. Nutr. 134:962S967S.

Zhong, Q., and M. Jin. 2008. Enhanced functionalities of whey proteins treated with supercritical carbon dioxide. J. Dairy Sci. 91:490-499.

Zougagh, M., M. Valcárcel, and A. Ríos. 2004. Supercritical fluid extraction: A critical review of its analytical usefulness. Trends Analyt. Chem. 23:399-405. 